\title{
Policy Design In Professionalism-Based Implementation Of Hajj Pilgrimage
}

\author{
ByRahmatJunaidi, ThohirLuth, M. Ridwan, Sihabudin
}

\begin{abstract}
In the perspective of professionalism, competency, ethic code and suitability in applied regulation are considered vital in running the implementation related to state affairs accordingly. Another approach such as maqashid al-syariah is seen to give bigger pressure to the propriety in Islamic dogma as a regulator in proper implementation in state affairs. This research aims at investigating the appropriateness of Act No. 13 Year2008 which regulates the implementation of hajj pilgrimage according to the two perspectives through normative-juridical studies on policy design, political reflection of law, and law construction for the implementation of hajj pilgrimage. From the evaluation based on professionalism perspective and maqashid al Syariah, it was found that there was some misconduct which required correction according to the aforementioned Act. Therefore, some suggestions were given to fix the implementation of Hajj pilgrimage with an expectation that the future implementation ofHajjprogramme will be based on professionalism andmaqashid al-syariah principles.
\end{abstract}

\section{INTRODUCTION}

Organising Hajj pilgrimage dates from the period of Dutch colonialism. In earlier time, the existing regulations seemed to give troublesome situation for pilgrims as a result of war of Diponegoro in 1825 . There was a kind of restriction proposed by Christian SnouckHurgronje in the late $19^{\text {th }}$ century, the period of which Indonesian communities in Saudi Arabia were suspected to be potentially in rebellion because they were not well-organised and watched. From this restriction by Hurgronje did Dutch government establish an agency providing full service related to Hajj pilgrimage to the pilgrims in Jeddah. This was also aimed to prevent the transmission of epidemic disease from and to Dutch East Indie. At the beginning of the $20^{\text {th }}$ century, colonial government tended to be more lenient with its political ethical structure. PelgrimsOrdoenantieStb No. 698 was released in 1922 to regulate the Hajj pilgrimage from Dutch East Indie, and this regulation was revised with pelgrimsVerordening in 1938.

After the Independence, the Old Order had constructed some rules regulating Hajj pilgrimage since 1960 in the Department of Religious Affairs. In 1966, the government in the era of Dwikora II Ministries appointed KH FaridMa'roef as the young minister of Hajj in his era. In the New Order, the national guidelines of Indonesia involved legal scope which regulated Hajj pilgrimage. Moreover, two new regulations such as those in Presidential Decree No. 22 Year 1969 and Presidential Instruction No. 6 Year 1969 were imposed. Following these regulations, in 1981, Presidential Decree No. 53 Year 1981 was released. In the late $20^{\text {th }}$ century, Socio-political condition led government to releasing the Presidential Decree No. 62Year 1995, followed with Presidential Decree No. 81 Year 1995 and Presidential Decree No. 119 Year 1998. The law in the first reformation era regulating the implementation of Hajj pilgrimage was stated in the Act No. 17 Year 1999 concerning the implementation of Hajj Pilgrimage. Hajj Pilgrims is now regulated in the recent law stated in Act No. 13 Year 2008

Act No. 13 Year 2008 highlights principles of Hajj pilgrimage implementation where "the implementation of Hajj Pilgrimage is conducted according to principle of justice, professionalism and accountability under the nonprofit principle". From these three principles in Act No. 13 Year 2008, the professionalism principle requires more attention, as this principle is considered new and has not been stated in previous Acts concerning Hajj Pilgrimage. The question that should be raised is that whether the professionalism principle is really implemented. In order to find out the substance of law, the structure and culture of law in which the Act is implemented also need to be taken into account. Furthermore, this research aims to investigate the construction of law in policy design related to the Professionalism-based implementation of Hajj Pilgrimage.

\section{Policy Design}

Policy brings a wide scope reflecting an objective and aspiration of the future providing guidelines to reach the objective". Policy making is a manifestation of authority so that the policy design will in turn be correlated with one of theories of authority as proposed in the following: the first theory comes from Schneider 
and Ingram concerning socio-constructive-based policy design. This theory states that policy is designed in the process of construction of social science about the identity of targeted population in the context of relation between institution and power. This context involves two types such as opportunity and technocracy. In the opportunity context, policy makers prioritize individual interest to rule the policy goals. The policy made usually sees who holds the right or no right to determine which side is beneficial to the policy makers. In the later context, science leads. The researches with the objectives focusing on public institutions are carried out, and conclusion is adopted to form a policy that is beneficial to society. Different context brings different strength and shortcomings, and it takes into account the professionalism and participation. In opportunity context, participation serves as the main principle because public participation determines where the policy makers would bring their policy to gain as many benefits as possible. On the other hand, in participative context, professionalism is the main principle, and public community serves as passive actors who rely on the opinions given by experts and analysis results.

Meanwhile, the theory of structural interest by Alford mentions that networks which hold structural interests make a system. Structural interest is defined as an interest which is gained or apart from the formation of public service organizations. This interest comprises dominant interest, challenging interest and repressed interest. In the context of health policy, for example, the dominant interest is represented by health care professionals; challenging interest is represented by companies; and the repressed interest by community. This theory, however, has been criticized, for it only relies on pluralism and market economy. In the perspective of developing countries, this does not tend to occur as the policy has tendency to be more monopolistic and the economy tends to be more centralistic. This weakness is also experienced in the theory of policy making by Bentley and Truman who argue that there is a horizontal relation in policy design among government, administration and organized interests which tend to be more flexible and, therefore, keep changing. Another theory of policy making called neo-corporatism confirming that policy design was made up by the elements such as hierarchy domination, limitless access, selectivity, and group structure. This theory is considered rigid to be applied in developing countries, and the problem lies in the act of underestimating the two actors: government and private sectors.

Looking at the aforementioned aspects, this research tends to focus more on Alford's theory in policy design due to the following reasons: In spite of the critics delivered to this theory in regard with its reliance on pluralism and market economy, this theory is perceived to fit the Indonesian condition which, as seen, also relies on those two aspects. The implementation of Hajj Pilgrimage demands pluralism as it embraces four different legal systems: Indonesian, Saudi Arabia, Islamic, and international legal systems, while the market economy was reflected by the fact that Hajj pilgrimage involves costly preparation and financial circulation which then give market a space to get involved whenever the policy applies. Secondly, the policy design in the implementation of Hajj Pilgrimage recognizes the presence of the three interests where the dominant interest is represented by ministry of religion, the challenging interest is represented by private sectors, and the repressed interest is represented by Hajj pilgrims.

\section{Good Governance}

Governance shows how aspects such as nation, corporation, or other entities are ruled. Seen from its equivalence, governance demands a body called government. Purbopranoto confirms that governance can be viewed from either narrow or wide perspective. In a narrow perspective, governance is seen as a rule makers (legislatives), rule executives (bestuur), justice (rechtspraak), or police (politie). In this perspective, government tends to function as a rule executive or bestuur. Hadjon, however, describes government is attached to their two main functions: it involves government's activities, and it functions as government's organ embracing the entities of government. Moreover, Government's task involves ruling and organizing. Ruling is conducted by making rules applied in a community and organizing is done by providing facilities and infrastructures for the community. In Indonesia, this is done by distributing authorities horizontally in central and regional hierarchy and also vertically in state institutions.

The discourse of good governance in Indonesia has been published since 1978 by KuntjoroPurbopranoto in his book entitled BeberapaCatatanHukum Tata PemerintahandanPeradilanAdministrasi Negara. In this book, Purbopranoto underlined 13 principles of good governance as proper general principles of government, two of which serve as new principles adding the 11 principles proposed by Crince Le Roy. Modern good governance adopts eight main principlesproposed by the UN: (1) Public participation, (2) upholding the rule of law, (3) transparency, (4) Equality, (5) Responses to stakeholders, (6) vision-oriented, (7) accountability, and (8) effectiveness and efficiency. Two new principles are to be added by the government of Republic of Indonesia: (9) control and (10) professionalism. This research focuses on the principle of professionalism in order to look overthe implementation of Hajj pilgrimage in Indonesia. 


\section{Legal System}

Theory of legal system commonly applied in Indonesia related to the study of law is that by Friedman who divided law into three components: content of law, structure of law and culture of law. His theory tends to be interpretive. Previously, Hart developed a theory of positive legal system stating that law consisted of four components: primary rules, consideration, rule of recognition, and social source. Hart's theory was seen positive because it did not consider social aspects in influencing law. However, it is not $100 \%$ true. Hart compared primary rules and rule of recognition, where the primary rules stemmed from formal, written and distinct rules, while the rule of recognition was based on habits. The rule of recognition represents the unwritten rule and is recognized and accepted as a part of primary rules. Society serves as a source from which the rule of recognition emerges and hence the society is called as a social source, although it is known that the best rule of recognition comes from legal officials.

Hart's legal theory is considered weak because it merely explained the area of legal content. He explained the source of legal content embracing formal and customary law. This theory is not entirely wrong as it works on sub-system of the bigger system explained by Friedman. However, theory of pluralism of law by Menski and Chiba also works on the legal content and is perceived to be more relevant to the current researches. This theory explains that legal system comprises three components: common law, religious law and formal law.

The three theories make a complete legal system. The theory of law enforcement can also be drawn in order to explain the Friedman's structure of law. In addition, simply referring to the content of law will bring us to an understanding of each element coming from the content of law through pluralism of law. Furthermore, both religious and common law can be viewed as rule of recognition in a modern legal system based on the perspective of Hart. Common law is known as social reality; religious law emerges from individual reality (prophets, in a perspective of Islam, Prophet Muhammad), and formal law emerges from political reality. As a result, the legal system theory applied in this research is a modified theory consisting of the three Friedman's components: content, structure and culture. The element of content is divided into three: common law, religious law and formal law. In the context of this research, the only two elements of formal law and Islam are in the spotlight of this research. Structure emerges from the theory of law enforcement; culture starts from the theory of legal actors; and the aspect of Islamic law raised in this research is maqasid al-syariah or known as a theory of mutual benefit.

\section{Research Methods}

This research is categorized as doctrinal and normative-juridical. The analysis of legal materials will employ qualitative approach of deductive analysis.

\section{History of Acts regulating Hajj Pilgrimage in Indonesia}

\section{Results And Discussion}

In the beginning of $20^{\text {th }}$ century, colonial government revealed ethical political framework. In this framework, Muhammadiyah, the newly founded Institution, managed to establish a foundation giving service in Hajj pilgrimage which then became a trailblazer of what is currently known as Directorate of Hajj Affairs. PelgrimsOrdonantieStaatsblad No. 698 was released in 1922 to regulate the journey of Hajj pilgrims from Dutch East Indies. In 1932, pegrimsOrdonantie was revised due to insistence coming from the member of Volksraad, Wiwoho and his colleagues. They insisted that the special cruise ships for the pilgrims be made available in Indonesia. In earlier time, the Hajj pilgrims in Indonesia were transported by KONGSI TIGA, a trading ship. In the revised Act, article 22a, it was added that indigenous people were eligible to propose the special transportation for Hajj candidates. The Decree of Hajj was then revised with PelgrimsVerordening in 1938.

During the Old Order and the beginning of New Order, issues related to Hajj were only around regulatory policy and never touched the Legislation. In 1995, President Soeharto released a Presidential Decree No. 62 Year 1995 about the implementation of Hajj Affairs. Article 1 asserts "Implementation of Hajj affairs is the responsibility of the nation and is organized by government". However, Presidential Decree No. 53 Year 1981 states that there are three new activities concerning the implementation of Hajj affairs such as planning, Hajj implementation, administrative control, and Hajj implementation procedures. Presidential Decree No. 81 Year 1995showed revision in Article 15 emphasizing that the responsibility and authority of transportation minister in organizing the transportation for the Hajj pilgrims do not reduce the responsibility of Religious Minister, and PT Garuda Indonesia is authorized to facilitate the air transports for Hajj pilgrims and other national airlines companies may also be involved in the cooperation.

The two aforementioned decisions eliminated the cost paid by the pilgrims (ONH Plus) and gave authority to Department of Religious Affairs. This Year, the number of Hajj pilgrims in Indonesia excesses the standardized quota agreed in Islamic Organization Conference in Amman in 1987 stating that a country is allowed to send only $0.1 \%$ of its Muslim population for Hajj Pilgrimage annually. Since then, the candidates of 
Hajj pilgrims should be put in waiting list so that it is not possible for the candidates to start the Hajj program in the Year they register, except when they were registered in 1999 when monetary crisis started to take place. To regulate such an issue, Department of Religious Affairsdevelops integrated computerized system of Hajj in association with PT Garuda Indonesia and banks in Indonesia.

The management of Hajj pilgrimage expenses $(\mathrm{ONH})$ and pilgrims' fund (DAU) was organized by government in 1996. In 1996, Soeharto issued Presidential Decree No. 35 Year 1996 concerning the body responsible for fund management for Hajj in Indonesia, and this responsibility was held by a minister of Religion (Article 6). Several elements and community organizations were involved; finance minister and Governor of Bank Indonesia were authorized as trustees; Minister of home affairs was authorized as regional supervisor; and the president was responsible for supervision of the central areas. Apart from Supervisors and trustees, the members of this management body consisted of 11 people, five of which represented government, and the other six were for Islamic Community Organization. Of those 11 members, Religious Minister served as a Head, Directorate General of Islamic Community Guidance and Hajj affairs as a secretary, and the treasurer of $\mathrm{ONH}$ as a treasurer. The other two of the members were General Secretary of Religious Affairs Department of Republic of Indonesia and General Inspector of Religious Affairs Department of Republic of Indonesia. Moreover, the members coming from Islamic community organization involved the Head of Ulama Indonesia Council (MUI), the Head of central Muhammadiyah, Rois'amSyuriah NU, the general Head of the boards of DakwahIslamiyah Indonesia, the general Head of DakwahIslamiyah Council, and the general Head of Fraternal Association of Indonesian Hajj.

The presence of Act No. 17 Year 1999 about the implementation of Hajj pilgrimage serves as the initial pillar of Hajj pilgrimage implementation in reformation era. Act No. 17 Year 1999 gives total authority to the minister of Religion in organizing the implementation of Hajj pilgrimage. This Act was made amid the unstable condition of the nation where the reformation era had just begun and the shift of ministries and president started to take place. Without anyprofound analysis, Act No. 17 is in its capacity to provide efficient regulation recalling that financial problem of ONH was not taken as direct responsibility of Religious Minister, but it should be under the review of President and House of Representatives of Indonesia.

The fatal shortcoming of the previous Hajj pilgrimage program is that it overlooked the refreshment for the pilgrims. In 2006, famine attacked regular Hajj pilgrims when they were performing the ritual called Wukuf in Arafat (Wukuf-e-Arafat) due to the late provision of refreshments by food caterer. This problem was triggered by the fact that food catering in Medina and Arminawas monopolized by particular caterers. This issue was occurring together with the steps the government was taking related to efficiency in financial aspect by providing free food for nine days in Medina and by divertingthe indirect fund from the pilgrims to government. It is hard to see that those two issues are not correlated. This occurring was not only against the objective of Act regulating Hajj program Year 1999, but it was also contrary to Act of anti-monopoly practice. Due to this famine tragedy, the Hajj activities were interrupted, so was their fervency when praying. From this tragedy, President issued Presidential Decree No. 1 Year 2007 concerning the formation of investigation team and the evaluation in implementation of Hajj pilgrimage year $1427 \mathrm{H}$.

After the revelation of the biggest corruption case found in the body of Hajj implementation, the President released Act No. 13 Year2008 which revised the system of implementation of Hajj pilgrimage. Several recommendations regarding the fixing and notions coming from experts were considered in term of the construction of this Act. One of the revisions involves setting apart the function of implementation and superintendence of Hajj pilgrimage from Religious Ministry. This act was formed by Indonesian Hajj Superintendents Commission (KPHI) substituting Indonesian Hajj Superintendence Body. KPHI was expected to be an independent commission although its members were appointed by the Religious Ministry. Another efficiency related to pilgrim funding was in the reduction of the pilgrimage cost as the pilgrims are to pay the rest of the cost. The hajj pilgrims are responsible for the air fares, accommodations, and other compulsory expenses in Saudi Arabia. Other cost such as human resources responsible for the Hajj program and the superintendents from the House of Representative, Supreme Audit Agency (BPK), and KPHI are funded by the government.

\section{Analysis on Legal System of Act No. 13 Year 2008}

The analysis of legal content compares Act No. 13 Year 2008 with Act No. 17 Year 1999. The result of the analysis brought some general rules in both Acts implying that the new Act is more professional in comparison with the old one. This matter is proven by the availability of relevant definition with the Islamic rules, where the definition related to the pilgrims is simplified; the definition of the House of Representative of Indonesia and KPHI are included; the definition of Hajj Pilgrimage Fund (BPIH), ministers and pilgrims' fund (DAU) are more specifically made; Pilgrims' Fund Body (BP DAU) is more professionally defined; rights and responsibilities are fairly distributed to the pilgrims; and the duty of the government is more concretely defined. However, a number of shortcomings are waiting to be fixed for the more professional Hajj pilgrimage 
implementation. Those shortcomings involve the shift of objective management system to subjective one. Moreover, the accommodations were not relevant to Act No. 4 Year 1992 concerning the housing for the pilgrims, followed by the exaggerated definition of transportation, the absence of Hajj season definition, and ambiguity in the definition of Hajj management.

From the analysis of principles and objectives, it can be concluded that the two Acts hold the principles related to the bases of policy making. There is a sharp difference in term of the norm basis of the two Acts. Although both Acts hold on the principle of justice, the new Act clings to the principle of professionalism and accountability. The presence of different principles reveals the different background of each Act. The old Act developed during the transition period when the national security was disturbed so that the principle of legal protection and certainty was prioritized. On the other hand, the new Act developed in a stable security and economic condition so that administrative-based principles such as professionalism and accountability were put ahead. Different principles bring different characteristics to both Acts. It, then, goes without saying that the new Act is considered more professional than the old Act. When correlated with the analysis of general provisions, the two Acts are consistent enough in applying the principles they hold, and the new Act tends to be more consistent than the old Act in applying the principles in its general provisions.

From the analysis of organization, it can be drawn that the new Act is better as it is more professional. It is proven by the fact that the implementation of Hajj pilgrimage is divided into smaller elements and, therefore, it can be easily managed and organized. In addition, the number of pilgrims who are organized by the Minister of Religion multiplies, where it can give policy hierarchy, and the authority owned by the Religious Minister is limited recalling that the Minister is authorized to form PPIH.

\section{Analysis of the Structure of Law}

The analysis of legal structure in Act No. 13 Year 2008 is based on the content of the Act, especially concerning the role distribution in the implementation of Hajj program. Such an analysis directly compares the rules with the theory of authority. It was shown in the analysis result that, in the structure of law, there were still a number of shortcomings in either authority or the responsibilities of the involved participants in the Hajj pilgrimage implementation. This situation needs fixing, for the principle of the new Act involves professionalism in which the clarity is demanded so that the existing legal structure can run as expected without any single conflict in both role and authority. The shortcomings could be considered in the revision of the new Act that has been made, where the shortcomings may involve: (1) Classification of government function which is not inter-departmental remembering that almost all authorized responsibilities are delegated to the Minister of Religion, (2) the pilgrims' right over the refreshment are not clearly stated, while the pilgrims deserve the refreshment (Article 7(b)), but it is not the government's responsibility to make the provision of the refreshment (Article 6), meaning that the provision of the refreshment is the responsibility of the private sector (Article 10(2)) e and (Article 40(c)). In a good way, this reduces the possibility that monopoly happens but on the other way around, it gives a sense that the responsibility of the government seems loose.(3) the absence of hierarchy coordination, (4) unregistered security services in the Hajj pilgrimage program, (5) too broad interests of the government in KPHI, (6) the role of House of Representative (DPR) as report receiver, not as the body which accounts for this pilgrimage program.

\section{Analysis of the Culture of Law}

Based on the analysis in the culture of law, it was found that every party was influenced by several environmental aspects. Then, it may spread to social behavior of actors to state law. Among the different cultures, the presence of Act regulating Hajj pilgrimage creates different reactions given by several actors. However, the reactions emerging were due to the cultures to which they hold. The aspects involved were: (1) professionalism issue faced by the government represented in the insufficient performance of the government due to several shortcomings previously identified, (2) professionalism issue faced by KPHI represented in compromises done to make reports look good but actually unprofessional, (3) in Pilgrims' Fund Body (BP $\mathrm{DAU})$, the existence of professionalism issue was triggered by the income in the balance of pilgrims' fund would face some problem because the Pilgrims" Fund Body (BP DAU) was directly associated with the party who was responsible for the implementation of the Hajj program and, at the same time, under the control of superintendents and governing boards of BP DAU. (4) The Ministry of Religion still monopolized the implementation of Hajj pilgrimage. (5) Other Ministries such as ministry of Finance, Foreign Affairs, Law, and Human Rights, and Transportation did not show maximum performance, for they were not authorized to account for this program but to only coordinate, and (6) another ministry which should have been involved such as Ministry of Housing.

\section{Analysis of Maqashid Al Syariah}


The analysis of maqashid al Syari'ah was carried out by comparing the relevance between Islamic Law in Qur'an concerning either the Hajj implementation and policy or the legislation of Republic of Indonesia. In this analysis, there are three values: relevant, doubted, and relevant to the principles of maqashid al syari'ah. Relevant means equal to what is instructed in Qur'an. Doubted means that the steps are still in dispute whether they are relevant to the Islamic rules in the related verses of Qur'an or not. The implementation of the principles was aimed to modify the implementation of Hajj pilgrimage so that the instructions in the related verses were not implemented entirely or partly. The eight aspects of Hajj implementation carried out by government are considered relevant, but two are doubted and four are relevant to the principles in maqashid al syari'ah. The implementation considered relevant comprises the following facts: (1) sa'I is included as a Hajj element, (2) Hajj is organized in home affairs, (3) Hajj is not considered compulsory during war periods, (4) the inspection of provision for Hajj pilgrims is made available by government, (5) Hajj is only carried out in Mecca, (6) Hajj is compulsory for those who have financial and physical strength, (7) Hajj is not more important than Jihad, and (8) Hajj should be supported by the availability of transportation. The implementation which is still doubted embraces the following elements: (1) Hajj pilgrimage is limited to three days in Mecca and (2) dhikr in three particular days (11,12, and 13 Zulhijjah), and the implementation of Hajj considered relevant to the principles of maqashid al syariah are as follows: (1) There is no regulation in rafats, fasik and arguing, (2) privatization in Hajj is non-profit, (3) There is prohibition in spreading Islamic doctrines negatively upon pilgrims' arrival to their home country, for it is against the law in Article 29 paragraph 2 in Indonesian Constitution 1945, and (4) the requirement to meet the vow (nazar) is not regulated.

Generally seen, the implementation of Hajj by the government is literally relevant to the Islamic Law in Qur'an. The quality of literal relevance and relevance in maqashid al syari'ah needs to be studied; is literal relevance is better than relevance in the perspective of maqashid al syari'ah? Here the principle of professionalism demands professional ability to foresee problems entirely and put the knowledge to use to do significant good deeds. According to this reason, the principle of professionalism, therefore, puts ahead the relevance to the principle of maqashid al syari'ah. In short, relevance to maqashid al syari'ah is much better than the literal relevance. With this principle, it can be concluded that the Hajj implementation is not yet maximum in term of implementing the Islamic Law. Therefore, it is considered less optimal in applying what is regulated in Article 29 (1) Indonesian Constitution 1945.

\section{Analysis of Construction of Law}

The analysis of construction of law is divided into three: analysis of Hajj pilgrims, analysis of implementation of Hajj pilgrimage, and analysis of culture in the society.

\section{Hajj Pilgrims}

The number of the Hajj pilgrimage candidates which exceeds the quota presents as the main problem. The waiting time for the candidates of Hajj pilgrims is 5 years, which means that the candidates will have to wait to be dispatched for Hajj pilgrimage 5 years from the time they are registered. The political principle of law to determine the national quota also serves as international law agreed in OIC Summit in 1987. In this summit, each member state was required to send one in a thousand pilgrims of the total of Moslems in each state. This quota system was applied due to the increased number of Hajj participants which then led to the logistic and security problems. Meanwhile, first-come-first-served system is also applied by the government in order to overcome this excessive number of participants. In Pakistan, the registered names of the Hajj participants are randomly picked to fill the quota of the Hajj pilgrims. Interestingly, in Turkmenistan, the Hajj pilgrims who are not dispatched to Mecca are facilitated to do internal Hajj where they are diverted to 38 religious locations in their own country instead of Mecca.

Each system mentioned above has its own advantages and drawbacks. In a queue system, every participant of Hajj pilgrimsis guaranteed to be dispatched; the only problem is that they have to wait for five years to be dispatched to Mecca. Within 5 years, unexpected changes such as socio-economic condition of the pilgrims and global political condition may happen. Some applicants of Hajj pilgrimage who were registered in 2004, for example, were unexpectedly infected by swine flu virus in 2009 before they had their chance to leave for Mecca. In 1999, a great number of Hajj applicants cancelled their journey to Mecca simply because there was political-economic crisis in Indonesia. Worse still, in a long run, the waiting time of Hajj pilgrimage will possibly be longer than it is today. In 1990s, the waiting time was only one year or two, and it now reaches up to 5 years of waiting time, and it is predicted that in the next 30 years, the waiting time will possibly be up to 10 years, and within 10 years, some of the elder pilgrims may die while waiting for their journey to Mecca.

In a lottery system, all applicants are not guaranteed to be dispatched to Mecca, as it depends on the luck everyone has. There is always possibility that a person has to wait year by year to go pilgrimage to Mecca until he/she dies as his/her name never comes out on the lottery. The good side is that those whose names are 
called will be dispatched without having to wait. Moreover, being called as a 'winner' in the lottery may psychologically affect their feeling that their good luck is a matter of Allah's will.

In internal Hajj system, the Hajj applicants who do not go pilgrimage are diverted to other different holy locations other than Mecca, and such substitution is valid. This diversion to some holy locations in their own country is difficult to be accepted due to the fact that Hajj pilgrimage in Mecca gives different sense of significance from that of internal Hajj. Sociologically, Hajj is the moment when Moslem people around the universe gather in one center where they can get socialized and do the prayer together. Moslem people participating in internal Hajj cannot have such a moment, except for the internal Hajj participants of Saudi Arabia. Moreover, the Hajj pilgrimage is a set of rituals which is literally explained in Quran. The diversion of the holy places like in internal Hajj due to emergency reason will trigger more development in the infrastructures resembling the locations of Hajj rituals as written in Quran. When such a development does not exist, there will be a mixed understanding whether the pilgrimage is considered Hajj ritual or just a common pilgrimage to the tombs of saint people. Such a pilgrimage to the tomb of saint people is commonly seen in Indonesia. It is believed that this kind of pilgrimage may lead the pilgrims to the practice of idolatry, where they believe that those saint people are equal to the position of prophets or even God who can grant their wishes.

To avoid those negative possibilities, it is perceived that direct or indirect international lobbying to increase the quota of Hajj pilgrims in Indonesia through the modification of Hajj period needs to be taken into account. In addition, internal approach such as regulating the pilgrims not to join the Hajj program more than once a year needs to be taken.

\section{Hajj Institution}

This part analyzes any possible problems in institutional points of view by giving review to existing problems emerging from each institution which is directly or indirectly involved in the implementation of Hajj pilgrimage program. Recalling that the Hajj pilgrimage is a national program, it involves varied and a large number of institutions such as Ministry of Religion, Supporting Ministries, regional government, superintendents, Supreme Audit Agency (BPK), social, private and legislative institutions.

Problems in Ministry of Religion embracefeudalism and paternalistic system which has developed for years, which are fixed with fit and proper test-based recruitment. Problems in the Supporting Ministriesnot only involve Ministry of Health but also other Ministries in association with the Ministry of Religion. This can be overcome by directly delegating the responsibility to each Ministry. The supporting Ministries, except the Ministry of Health, have been associated with the Minister of Religion. It is advisable that the supporting Ministries take action without coordinating with another Minister to save time and be more professional, while working without coordination triggers disharmony. Due to this possible lack, a special institution managing Hajj program is required as to plan and regulate Hajj pilgrimage. This institution such as National Disaster Management Agency (BNPB) is supposed to superintend all Ministries related to the implementation of Hajj pilgrimage in term of disaster management. Some duties are to be delegated to private sectors except the duties of the Ministries of Foreign Affairs, Law and Human Rights, Communication and Telematics, and Finance.

In regional government, the problem is dominated by paternalism in business competition. To overcome this problem, implementation of e-procurement and fair business competition principles may come to the rescue. In superintendence agencies, KPHI is found to be bound with the authority of Religious Minister. To tackle this problem, KPHI is supposed to be an independent institution which is out of the authority of Religious Minister. In a diplomatic area, the distinct difference in the characteristics of Saudi Arabia and Indonesia can be overcome through quota policy in the form of compensation for the government of Saudi Arabia.

Large amount of fund in Supreme Audit Agency (BPK) is prone to any chance of corruption. To anticipate this occurring, the Act regulating the management of finance for hajj and the pilgrims' fund was made. It is generally understandable that the management of the remaining fund in Hajj program is the responsibility of BP DAU for the sake of the involved people, but, in the perspective of professionalism, this is not acceptable. The remaining amount of fund coming from the pilgrims should be returned to the pilgrims.

The professional step that can be taken is not to abolish BP DAU, but rather to return the remaining fund paid by the pilgrims unless they agree to leave the rest of the amount to be managed as a charity. So, practically, the pilgrims will be offered two choices whether they want the rest of their money back or they will put it for charity through BP DAU.

Abolishing the responsibility of DAU seems to be irrational and contrary to the principle of humanity, for the existence of DAU represents the implementation of Maqashid al Syariah. Discourse concerning DAU dates back 1994 when the Hajj seminar was held in Jakarta. In this seminar, a speaker from Malaysia delivered his speech about Hajj saving (Tabung Haji). This idea soon attracted 500 religious leaders representing NU, Muhammadiyah, and other organizations. They expected this saving could also be applied in DAU. DAU was established to help with the Hajj implementation, education, the development of house of worship, and poverty 
eradication. Their proposal then brought to the Presidential Decree No. 35 and No. 52 Year 1995. DAU was collected according to the efficiency of each Hajj season, one of which was based on foreign exchange.

Furthermore, according to the Presidential Decree No. 22 Year 2001, DAU could come from another source which is relevant to the Legislation. In addition, this Presidential Decree also extends the function of DAU in term of education and propaganda, health, social and economic purpose, development of the house of worship and its infrastructure, and the implementation of Hajj pilgrimage.

Ironically, the pilgrims' fund (DAU) is proven to have conducted misuse along the history of its existence. It indicates that the pilgrims' fund (DAU) not only gives advantage but also disadvantage. When some amount of the fund is returned to the pilgrims, the disadvantage may not be present; the advantage is more obvious, for the money partially given to Pilgrims' fund body (DAU) is put in charity. Even though the amount left in the body is not quite large, doing such a good deed may bring merit to the pilgrims themselves. When the pilgrims' fund (DAU) is out of its capacity in Islamic development, the fund organized by Board of Finance for Hajj can financially support through investment of Hajj Pilgrims who haven't had their chance for Hajj pilgrimage.

However, what remains to be the problem is that the community organizations are not representative enough in term of ideology. The solution to this problem is to embrace fundamental-based community organizations. Private sectors also have the problems when the Ministry of Religion serves as a regulator and operator simultaneously. What may solve this problem is to establish an institution regulating Hajj program as a regulator while the operation should lie in the responsibility of private sectors in the related scopes of Ministries, including the Ministry of Religion through tender program and in accordance with the principle of fair business competition. In a legislative system, the slow implementation of regulations made after the making of Acts also serves as a problem which may be solved by referring to Articles restricting the deadline of the issuance of regulations as proposed by Acts.

Apart from the institution responsible for the fund management, another institution such as Islamic Institution of higher education under the umbrella of the Ministry of Religion also needs to be put in the spotlight. Although a particular institution under the Ministry of Religion dealing with the Hajj program is available, there is no such major or study program in Islamic institution of higher education teaching subject related to Hajj program. This fact brings us to a doubt concerning the lack of professionalism due to the lack of ideas or human resource supposed to be given by the institution. National Disaster Management Agency, for example, does not have a formal institution giving particular education related to the disaster management. However, this agency is associated with National Defense University, so that access of ideas and eligible human resource are open to the agency, bringing professionalism in disaster management. It applies as well in other institutions such as the Ministry of Culture and Education or the Ministry of Industry. The absence of inputs of ideas from education institutions under private management, the professionalism related to providing service in Hajj program and the function of the education institution under the Ministry of Religion will be questioned.

\section{Social Culture}

Indonesia is known as a nation of collectivity, where standardization is hard to implement because everything is constructed under mutual agreement. This is implied in point 4 of Pancasila, the State Philosophy concerning deliberation principles. In the perspective of professionalism, this is considered as a problem, and, unfortunately, this problem triggered corruption, collusion, and nepotism (KKN) in Indonesia. The government works based on standard while the society overlooks the existing standard. It, then, goes without saying that President SusiloBambangYudoyono decided to assess the implementation of Hajj pilgrimage according to the perspective of societies instead of the success of the implementation in line with the particular policies and management.

Socialization comes to the rescue for this problem, for it involves the emphasisgiven by the government regarding the importance of standardization and how this aspect is seen as linear to the advantages felt by societies. Recalling that decision is made by a group of people, it is important that the socialization does not head for one direction. The New Order is proven sufficiently effective in term of the socialization carried out by having face-to-face meeting between a headman of an area with the societies so that the agreement and commitment are reached. During the reformation era where advanced technology had already existed, socialization was hard to implement. The government's preference was more into putting advertisement in mass media such as television, and for sure the direct presence of societies as audience was not required.

Traditional approaches should have been more effective than the modern ones, for the majority of Hajj pilgrims are elderly peopleand the culture they hold dates back the colonial era. It can be assumed that the culture of collectivity is strongly attached. On the other side, individual (non-collective) culture brought by urbanization and national media only effectively affects the young and elderly Hajj pilgrims coming from big cities, and the collectivity in some other big cities is still considered strong. This is proven by the fact that the 
speeding ticket given by the policeman to the rule breaker always ends up in the agreement of both parties reached on the street, not in the court.

\section{Conclusion}

This research found that policy design related to the Hajj pilgrimage program brings difference among the colonial, Old Order, New Order, and reformation era. During the colonial era, policy was addressed to restricting the movement of Hajj pilgrims. In the Old Order, the implementation of Hajj program was addressed to liberalism. In the New Order, Hajj implementation was delegated to the government with the consideration that Hajj management by private sectors may bring problem of professionalism. During the reformation era, the Hajj implementation was re-addressed from the transition of security paradigm to paradigm of good corporate governance.

In several eras, professionalism serves as a reason to change policies. In the era of colonialism, community organization demanded the improvement in non-public services in Hajj shipping. The New Order and Old Order could be integrated as long as paradigm of professionalism is not solely emphasized in the Old Order, but the New Order should apply it to justify the process of Hajj implementation by government. In the era of reformation, economic and political stability served as a booster to the principles of professionalism in Hajj implementation.

In general, policy design regulating the implementation of Hajj program in the perspective of professionalism principles in the new Act needs fixing. In term of the content, there are ambiguity and incompleteness. In term of the structure, some shortcomings in the authority of several sectors are still found. In the cultural side, the new Act still compromises with the cultural background of Indonesia which prioritizes more the consensus than professionalism. The reflection of legal politics in policy design concerning the implementation of Hajj program in Indonesia has been competing with community, governmental, and private organizations in different level of power. Community organization is described as a party which deals with the general interest of Moslems, but this party is very heterogeneous and has had a great legal power descended as a historical legacy since the era of colonialism to the era of the New Order. In reformation, Islamic community organization should have gained priority, but the politics of security established in the beginning of reformation restricted the capacity of the organization. The suppression from private sectors which was stronger due to the global support for liberalism worsened the situation.

\section{Suggestions}

Based on the aforementioned analyses, suggestion is drawn as follows:

1. There needs to be a separation between the role of regulator and operator in the implementation of Hajj program. The role of regulator is under the Hajj National Body supervising Ministries including Religious Ministry. The role of operator is under the private sectors except for particular fields whose responsibilities are not possible to be delegated. The role of regulator in Ministries embraces the Ministry of Religion for the guidance and the management of pilgrims' fund (DAU), the Ministry of Health for the health and refreshment, the Ministry of Transportation to facilitate the transportation, The Ministry of Housing for accommodations, the Ministry of Law and Human Rights for immigration, the Ministry of Finance for customs duty, the Ministry of Home Affairs for mentoring the Hajj pilgrims, Bank Indonesia for the management of deposit funds, the Ministry of Communication and Informatics for socialization, the Ministry of Foreign Affairs for diplomacy, security and safety, and the Ministry of Cooperatives and Small and Medium Enterprises (SMEs) for Hajj attributes. The role of operator is in the private sectors of Hajj attributes, the management of deposits fund, accommodations, transportation, and refreshment by caterer.

2. Indonesian Hajj Superintendents Commission (KPHI) should be more independent than it is today. This may come into reality when the responsibility of Religious Minister to appoint the members of KPHI and/or suggest terminating the members of KPHI is designated to community organizations or Hajj National Body. Membership of KPHI should be increased in number with the proportion coming from the community twice as many as that of the government. The number of the members taken from the government should at least consists of nine members, seven of which represent the following ministries: the Ministry of Religion, the Ministry of Housing, the Ministry of Health, the Ministry of Foreign Affairs, the Ministry of Law an Human Rights, the Ministry of Transportation, the Ministry of Finance, and two of which also represents these two agencies: Supreme Audit Agency (BPK) and Anti-Corruption Commission (KPK). The representatives taken from community organizations should bring the elements of fundamental-based organizations such as FPI, HTI, or Mujahidin Council. Therefore, according to the perspective of professionalism, the ideal number of KPHI is 27 members. 
3. Deposits fund for Hajj should be managed by a special body which holds competency in financial management, not by the ministry of Religion which has competency in religious affair. The pilgrims' fund (DAU) should be paid voluntarily, so that the maximum advantage could be gained and the responsibility of Pilgrims' Fund Body (BP DAU) should not only go to the government but also to the Hajj pilgrims who put a trust for the management of their fund in the fund body.

4. The Ministries involved in the Hajj programs should be increased more in number than it is today. This can be done by embracing the Ministry of Housing for the accommodations for the Hajj pilgrims, and the Ministry of Communication and Informatics for the socialization of hajj reformation.

5. General provision in the Act concerning the Hajj should be fixed for the better professionalism and to avoid ambiguity. This is particularly done in the target of Hajj implementation, housing, transportation, Hajj season, and special Hajj program. The target of the implementation should comprise two elements such as the management of Hajj implementation in the old Act, and the satisfaction perceived by the pilgrims as stated in new Act.

6. The principle of fair business competition and transparency should be added in Act concerning the Hajj in addition to the existing principles: justice, professionalism, and accountability.

7. In addition to the technical knowledge, the Hajj pilgrims should also be introduced to the knowledge of the development of Islam especially in the propaganda. In this case, the role of the ministry of Religion is highly required, for the movement of the Religious Minister, in the principle of professionalism, is restricted to the development of the Hajj pilgrims. Therefore, it is expected that there will be a balance between the reduction of management authority and the addition of responsibilities in developing Islam.

8. The Ministry of Foreign Affairs should hold diplomatic discussion with the government of Saudi Arabia to increase the quota for Hajj pilgrims in Indonesia, and this can be done through compensation, with the reason that Indonesia has the highest number of Hajj pilgrims and Saudi Arabia is certainly the only destination for the implementation of Hajj program. Therefore, it is assumed that other members of OIC are encouraged to come up with revision related to the quota of Hajj pilgrims in either Indonesia or other parts of the world.

9. Government should restrict the Hajj pilgrims who attend the program more than once a year in order to maximize the five-year-waiting quota.

\section{Reference}

[1] Department of Religious Affairs, Republic of Indonesia. SekilasSejarahPerhajian Indonesia, Department of Religious Affairs, Republic of Indonesia, 2006

[2] Gayo, H.M. BukuPintar Haji danumrah. PustakaWarga Negara, Jakarta, 2003

[3] Hadjon, P.M. PemerintahanMenurutHukum, Surabaya, Universitas Airlangga, 1992

[4] Hadjon, P.M. PengantarHukumPerizinan, YURIDIKA : Surabaya, 1993

[5] Hoppe, R. The Governance of Problems: Puzzling, Powering, Participation, The Policy Press, 2010

[6] IMF, The IMF's Approach to Promoting Good governance and Combating Corruption — A Guide, Last Updated: June 20, 2005

[7] Kenis, P dan Volker Schneider, Policy Networks and Policy Analysis: Scrutinizing a New Analytical Toolbox, Frankfurt, Campus, 1991

[8] KomisiPengawasanPersaingan Usaha Republik Indonesia, EvaluasiKebijakanPemerintahterkaitdenganPersaingan Usaha in draft amendment of Act No. 17/1999 concerning Hajj implementation, KPPU, 2006

[9] Menski, W. Comparative Law in a Global Context: The Legal Systems of Asia and Africa, 2006

[10] Pemerintah RI. Book 2 RKP 2008

[11] Purbopranoto, K. HakAsasiManusia dan Pancasila. Jakarta: PradnyaParamita, 1982

[12] Raz, J. The Concept of a Legal System, $2^{\text {nd }}$ Edition, Clarendon Press, Oxford, 1997

[13] Saleh, A.C. Penyelenggaraan Haji Era Reformasi: Analisis Internal KebijakanPublikDepartemen Agama. Alvabet, Jakarta, 2008.

\section{Journals and papers}

[1] Clingingsmith, D., AsimljazKhwaja, dan Michael Kreemer, "Estimating the Impact of the Hajj: Religion and Tolerance in Islam's Global Gathering". Dubai School of Government Working Paper No. 08-04, May 2008

[2] Coleman, J.L. Rethinking Legal Positivism, USC Workshop, 2008Thomalla, F., RasmusKlocker Larsen, Fareedali Kanji, SoponNaruchaikusol, ChanyuthTepa, Bruce Ravesloot, and AtiqKainan Ahmed. From Knowledge to Action: Learning to go the Last Mile, Stockholm Environment Institute, 2009

[3] Ichwan, M.N. Governing Hajj: Politics of Islamic Pilgrimage Services in Indonesia Prior to Reformasi Era, Al Jami'ah, 46(1), 2008, 126-154

[4] Low, Michael Christopher, Empire of the Hajj: Pilgrims, Plagues, and Pan-Islam under British Surveillance,1865-1926. History Theses. Paper 22. 2007

[5] Osman, F.A. Public Policy Making: Theories and Their Implications in Developing Countries, Asian Affairs, 1999, 37-52

[6] USCIRF (United States Commission on International Religious Freedom). Annual Report 2011

\section{Internet}

1. Hukum Online. MarhabanKomisiPengawas Haji Indonesia, http://hukumonline.com/berita/baca/hol18888/imarhabani-komisipengawas-haji-indonesia

\section{Newspaper}

1. Jawapos, June 20, 2005, Mantan MenteriAgamaTarmiziSiapDiperiksaKasusKorupsiHaji. 


\section{Legislation}

1. Constitution 1945

2. Act No. 13 Year 2008 concerning the implementation of Hajj pilgrimage

3. Act No. 17 Year 1999 concerning the implementation of Hajj Pilgrimage

4. Act No. 4 Year 1992 concerning the housing and accommodations. 